\title{
ARAHAN POLA PENYEBARAN RUANG TERBUKA HIJAU IBUKOTA KECAMATAN TADU RAYA KABUPATEN NAGAN RAYA, NAD
}

\author{
Oleh : Linda Dwi Rohmadiani
}

\begin{abstract}
Abstrak
Proporsi Ruang Terbuka Hijau sesuai dengan Undang-Undang Nomor 26 tahun 2007 tentang Penataan Ruang pada wilayah perkotaan yaitu $30 \%$ dari luas kota. Ibukota Kecamatan Tadu Raya memiliki luas wilayah \pm 654 , 22 ha sehingga dibutuhkan 196, 266 ha yang terdiri dari $20 \%$ RTH publik \pm 130,844 ha dan $10 \%$ RTH privat yaitu $\pm 65,422$ ha. Penelitian ini memberikan arahan pola penyebaran ruang terbuka hijau disesuaikan dengan kebutuhan masyarakat di masing-masing wilayah. Proyeksi jumlah penduduk IKK Tadu Raya pada tahun 2031 adalah 2.122 jiwa dan proyeksi kebutuhan RTH-nya seluas $2.000 \mathrm{~m}^{2}$. Dengan rincian proyeksi jumlah penduduk dan kebutuhan RTH sebagai berikut: (1) Desa Alue Bata 887 jiwa dan $1.000 \mathrm{~m}^{2}$; (2) Gunong Pungkie 754 jiwa,dan $750 \mathrm{~m}^{2}$; (3) Desa Gunong Kupok 421 jiwa dan 250 ha; (4) Desa Gunong Sapek 59 jiwa dan $0 \mathrm{~m}^{2}$. Hasil akhir dari penelitian ini adalah berupa peta arahan dan pola sebaran RTH di tiap desa di IKK Tadu Raya, dimana daerah sebaran tersebut berdasarkan penggunaan lahan yang telah ada dengan mengutamakan penggunaan lahan dengan nilai landrent yang rendah yaitu diutamakan tanah kosong, semak, dan pepohonan.

Kata Kunci: Ruang Terbuka Hijau, Pertumbuhan Penduduk, Ibukota Kecamatan Tadu Raya
\end{abstract}

\section{PENDAHULUAN}

Ruang Terbuka Hijau merupakan suatu daerah hijau tanpa bangunan yang sebagian besar berupa hamparan tanaman yang terletak pada lahan yang luas sehingga dapat diakses oleh publik. Ruang Terbuka Hijau dalam Intruksi Mendagri No. 4 tahun 1988, menyatakan bahwa Ruang Terbuka Hijau yang populasinya didominasi oleh penghijauan baik secara alami atau budidaya tanaman, dalam pemanfaatan dan fungsinya adalah sebagai areal berlangsungnya fungsi ekologis dan penyangga kehidupan perkotaan. Selain itu, ruang terbuka hijau yang dibuat melalui pendekatan desain tata hijau membentuk karakter yang dapat menunjang secara ekologis, kegiatan rekreasi,dan menambah keindahan bagi lingkungan di sekitarnya (Peraturan Menteri Pekerjaan Umum No. 06 Tahun 2007 tentang Pedoman Umum Rencana Tata Bangunan dan Lingkungan).

Keberadaan ruang terbuka hijau dan lapangan olahraga sangat diperlukan terutama untuk memberikan kesegaran, kenyamanan, dan keindahan. Secara fisik daerah hijau dapat berfungsi sebagai tempat bermain anak-anak, sarana olah raga terbuka, dan sarana berkomunikasi antar penduduk sekitarnya.

Ibukota Kecamatan Tadu Raya memiliki tingkat perkembangan yang pesat karena adanya pengaruh dari berbagai aktivitas yang terdapat di dalamnya. Untuk dapat mewujudkan efisiensi pemanfaatan ruang sebagai tempat berlangsungnya kegiatan-kegiatan ekonomi, pemerintahan dan sosial budaya, maka kawasan perkotaan perlu dikelola secara optimal melalui penataan ruang.

Proporsi Ruang Terbuka Hijau sesuai dengan Undang-Undang Nomor 26 tahun 2007 tentang Penataan Ruang pada wilayah perkotaan yaitu $30 \%$ dari luas kota. Ibukota Kecamatan Tadu Raya memiliki luas wilayah $\pm 654,22$ ha sehingga dibutuhkan 196, 266 ha yang terdiri dari $20 \%$ RTH. publik $\pm 130,844$ ha dan $10 \%$ RTH privat yaitu $\pm 65,422$ ha. Tahun 2010, 95,12\% penggunaan lahan di IKK Tadu Raya masih merupakan RTH alami (sawah dan kebun) oleh karena untuk mencegah adanya konversi lahan pertanian menjadi lahan non pertanian (lahan terbangun) maka sangat dibutuhkan adanya pengendalian pemanfaatan ruang khususnya pemanfaatan ruang untuk ruang terbuka hijau baik berupa taman bermain, lapangan olah raga, makam maupun jalur hijau. Penelitian ini memberikan arahan pola penyebaran ruang terbuka hijau disesuaikan dengan kebutuhan masyarakat di masingmasing wilayah.

*)Dosen Perencanaan Wilayah dan Kota (PWK) Universitas PGRI Adi Buana Surabaya 


\section{METODE PENELITIAN}

\section{Metode Pengumpulan Data}

Pengumpulan data yang dilakukan dalam penelitian ini menggunakan dua sumber yaitu data primer dengan teknik observasi dan wawancara, dan data sekunder dengan teknik studi kepustakaan dan data instansi.

\section{Metode Analisis Data}

Metode analisis data yang digunakan yaitu:

- Metode deskriptif, yaitu dengan tabulasi, grafik, dan diagram untuk mengetahui karakteristik fisik, kependudukan, proporsi dan distribusi ruang terbuka hijau.

- Metode evaluatif, berupa: proyeksi kependudukan dan analisis kebutuhan serta pola persebaran ruang terbuka hijau.

\section{HASIL DAN PEMBAHASAN}

\section{Kondisi Fisik dan Kependudukan}

Secara topografis, IKK Tadu Raya sebagian besar terletak di kawasan perbukitan. Secara umum topografi wilayah Kecamatan Tadu Raya berada di lereng perbukitan $>40^{\circ}$ sebesar $0,37 \%$ dan dataran $0-3^{0}$ sebesar $67,35 \%$. Prosentase kemiringan lahan di wilayah penelitian secara lengkap dapat dilihat pada gambar 1 .

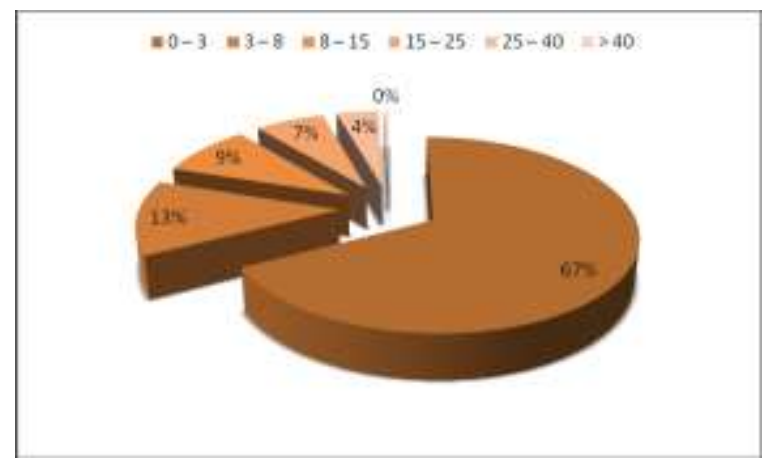

Gambar 1. Prosentase Kemiringan Lahan di Ibukota Kecamatan Tadu Raya

Kecamatan Tadu Raya adalah Kecamatan yang baru saja berkembang setelah terjadi pemekaran wilayah di Kabupaten Nagan Raya tahun 2007, maka pertumbuhan penduduk yang bisa terlihat dalam empat tahun terakhir (tahun 2007-2010) adalah sebesar 0,2\%. Jumlah penduduk tahun terakhir (tahun 2010) adalah sebesar 1.435 jiwa dengan kepadatan penduduk 2,16 jiwa/Ha. Kepadatan penduduk tertinggi pada Desa Gunong Pungkie sebesar 11,75 jiwa/ha dan kepadatan penduduk terendah pada Desa Gunong Sapek 0,54 jiwa/ha. Perkembangan jumlah dan kepadatan penduduk di wilayah penelitian menurut data BPS Kabupaten Nagan Raya dapat dilihat pada gambar 2 dan 3.

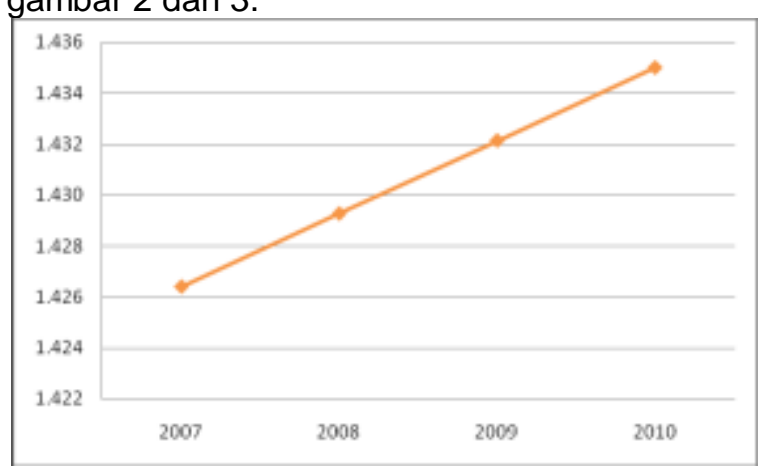

Gambar 2. Perkembangan Jumlah Penduduk lbukota Kecamatan (IKK) Tadu Raya Tahun 2007-2010

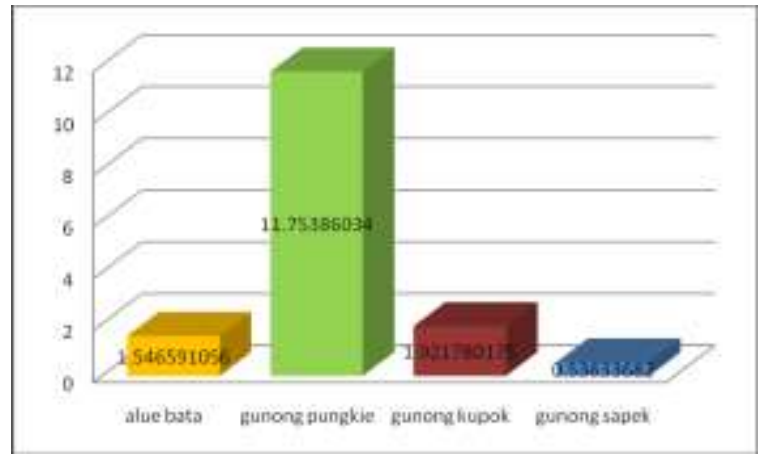

Gambar 3. Kepadatan Penduduk Ibukota Kecamatan (IKK) Tadu Raya Tahun 2008

Penggunaan lahan di lbukota Kecamatan (IKK) Tadu Raya pada tahun 2010 secara umum didominasi jenis penggunaan lahan tidak terbangun, baik berupa sawah, sarana olahraga dan makam dengan luas 640,479 $\mathrm{Ha}$. Sedangkan untuk lahan terbangun hanya sebesar $18,434 \%$ dari total luas wilayah 24,362 Ha.Pola penggunaan lahan di wilayah penelitian secara jelas ditampilkan pada gambar 4 dan 5 . 


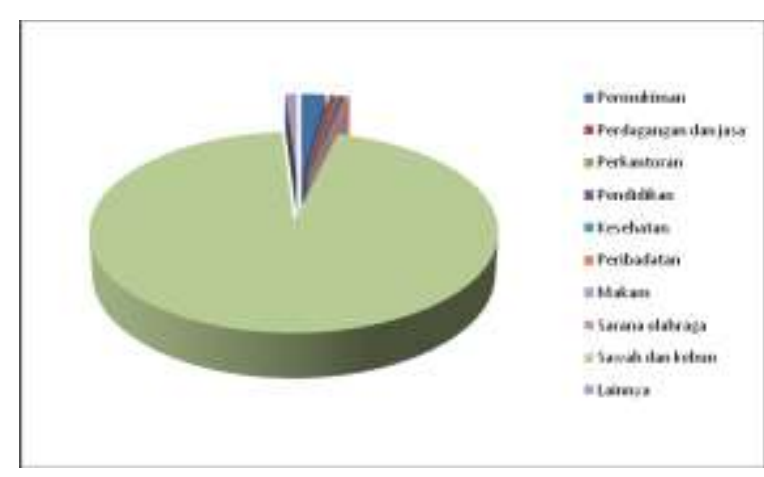

Gambar 4. Prosentase Penggunaan Lahan di IKK Tadu Raya Tahun 2010

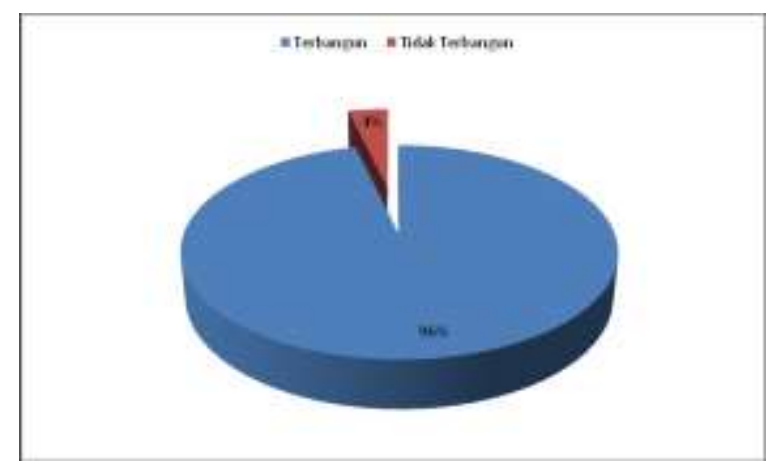

Gambar 5. Persentase Lahan Terbangun dan Tidak Terbangun

\section{Proporsi dan Distribusi RTH IKK Tadu Raya} Jenis ruang terbuka hijau yang ada di Ibukota Kecamatan Tadu Raya adalah berupa lapangan sepak bola sebanyak 1 unit, lapangan bola voli sebanyak 2 unit dan TPU sebanyak 1 unit. Selain jenis-jenis tersebut, di lbukota Kecamatan Tadu Raya juga terdapat banyak lahan kosong yang dipenuhi oleh tanaman liar. Pola persebaran ruang terbuka hijau di wilayah penelitian pada tahun 2010 secara lengkap pada gambar 7 dan 8 .

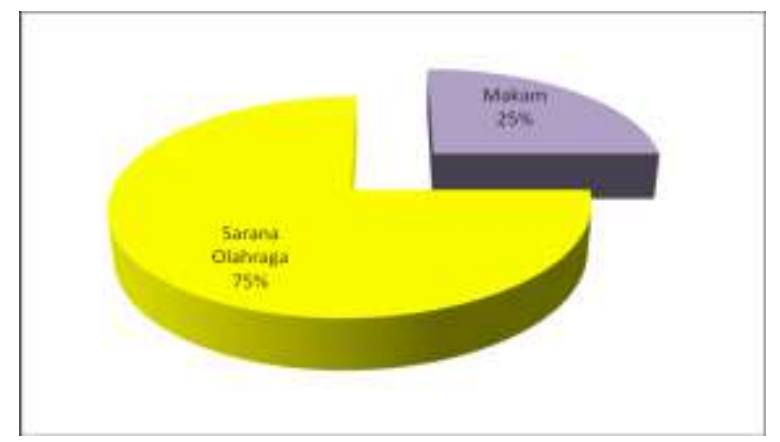

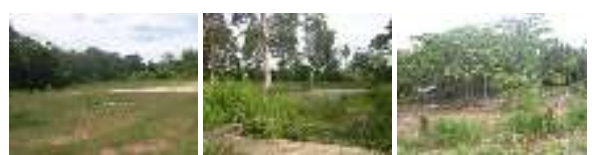

Gambar 7. Kondisi RTH IKK Tadu Raya

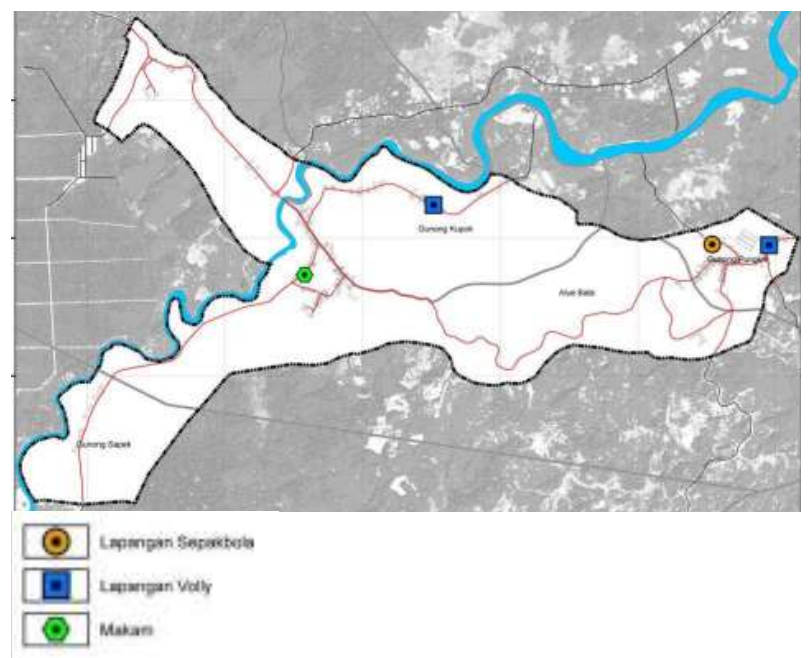

Gambar 8. Peta Persebaran Ruang Terbuka Hijau IKK Tadu Raya Tahun 2010

\section{Analisis Proporsi Ruang Terbuka Hijau}

Pada IKK Tadu Raya Ruang Terbuka Hijau hanya menempati komposisi penggunaan ruang sebesar $0,0012 \%$ dimana proporsi penggunaan lahan sebagai ruang terbuka hijau seharusnya sebesar $20-30 \%$ dari keseluruhan kawasan $(196,266 \mathrm{Ha})$.

$$
\begin{aligned}
\frac{\text { L. RTH }}{\text { L. kawasan }} \times 100 \%=\frac{0,0079 \text { ha }}{654,22 \text { ha }} \times 100 \% \\
=0,0012 \%
\end{aligned}
$$

Proyeksi Penduduk

Pertumbuhan penduduk jika disesuaikan dengan fungsi lbukota Kecamatan Tadu Raya yang merupakan pusat kegiatan di Kecamatan Tadu Raya, maka akan memicu pertumbuhan penduduk yang lebih besar. Kecendrungan pertumubuhan penduduk dikaitkan dengan fungsi wilayah perencanaan akan meningkat sebesar $20 \%$ per masing-masing desa dan per tahun. Kepadatan penduduk tertinggi pada tahun 2031 diperkirakan tetap di Desa Gunong Pungkie dan terendah di Desa Gunong Sapek. Perkiraan jumlah dan kepadatan penduduk di wilayah penelitian disajikan pada gambar 9 dan 10.

Gambar 6. Persentase RTH di lbukota

Kecamatan Tadu Raya Tahun 2010 


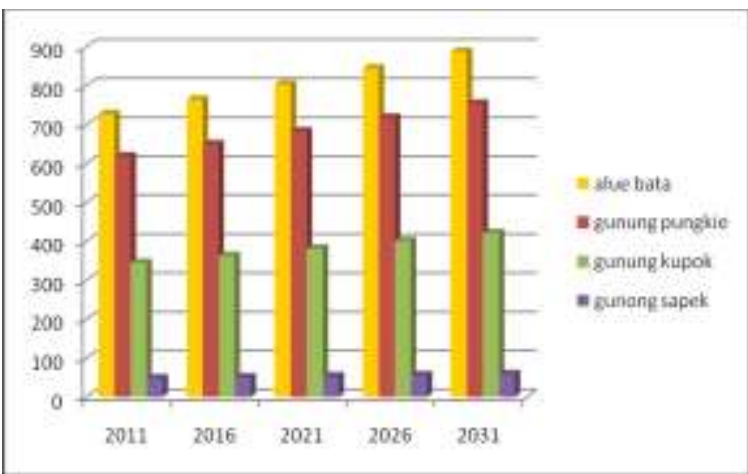

Gambar 9. Kecenderungan Perkiraan Jumlah Penduduk Ibukota Kecamatan Tadu Raya Tahun 2011-2031

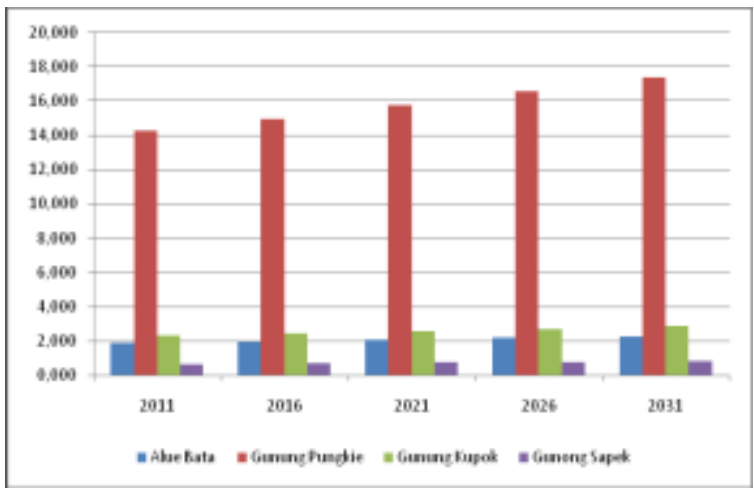

Gambar 10. Perkiraan Kepadatan Penduduk IKK Tadu Raya Tahun 2011-2031

Fasilitas olah raga di Ibukota Kecamatan Tadu Raya di antaranya lapangan sepak bola, lapangan bulu tangkis dan lapangan bola volli. Sedangkan fasilitas taman bermain dimanfaatkan untuk penduduk umur 0-7 tahun dan biasanya terletak di tengah-tengah lingkungan namun tidak terdapat di lbukota Kecamatan Tadu Raya. Fasilitas-fasilitas olahraga ini memberikan pelayanan skala lokal saja, yaitu hanya dimanfaatkan oleh penduduk desa di wilayah Ibukota Kecamatan Tadu Raya. Taman bermain di lbukota Kecamatan Tadu Raya belum tersedia (tingkat pelayanan 0\%) sehingga pada tahun rencana 2031 dibutuhkan 8 unit taman bermain. Radius pelayanan lapangan olah raga menurut SNI 03-1733-2004 sebesar $1.000 \mathrm{~m}$.

Pola hijau lingkungan perumahan adalah tamantaman yang dibuat berdasarkan kebutuhan ruang terbuka hijau dengan memperhatikan kepadatan penduduk. Sarana tersebut disamping berfungsi utamanya sebagai taman, tempat bermain dan lapangan olahraga, juga dapat berfungsi sebagai paru-paru kota. Kebutuhan ruang terbuka hijau perumahan, standarnya adalah sebagai berikut :

Taman dan tempat bermain untuk setiap 250 penduduk dengan luas lahan $250 \mathrm{~m}^{2}$ dan lokasinya dapat bersatu dengan tempat bermain dan olah raga.

$\square$ Taman untuk setiap 2.500 penduduk dengan luas lahan $1.250 \mathrm{~m}^{2}$. Daerah terbuka ini sebaiknya berupa taman yang dapat digunakan untuk aktivitas-aktivitas olahraga seperti volley dan badminton. Lokasinya dapat disatukan dengan pusat kegiatan masyarakat di tingkat RW.

Taman dan lapangan olahraga untuk setiap 30.000 penduduk dengan luas lahan 9.000 $\mathrm{m}^{2}$ yang dapat melayani aktivitas-aktivitas kelompok diarea terbuka seperti pertandingan olahraga. Fasilitas ini sebaiknya berbentuk taman yang dilengkapi dengan lapangan sepakbola sehingga berfungsi serbaguna dan harus tetap terbuka. Pohon-pohon peneduh juga dapat ditanam pada taman yang ada. Lokasi sebaiknya digabung dengan sekolah sehingga bermanfaat bagi siswa dan berfungsi sebagai peredam gaduh.

Pembangunan taman skala RT diarahkan tersebar di setiap komplek permukiman di Desa Alue Bata 4 unit taman bermain, Desa Gunong Pungkie 3 unit, dan Desa Gunong Kupok 1 unit taman bermain. Sedangkan untuk lapangan olah raga sudah terpenuhi karena di lbukota Kecamatan Tadu Raya sudah terdapat Lapangan olahraga sepakbola, bola volli dan bulu tangkis yang ada di Desa Alue Bata dan Desa Gunong Pungkie yang mempunyai skala pelayanan tingkat kecamatan. Lebih jelasnya dapat dilihat pada gambar 11 . 


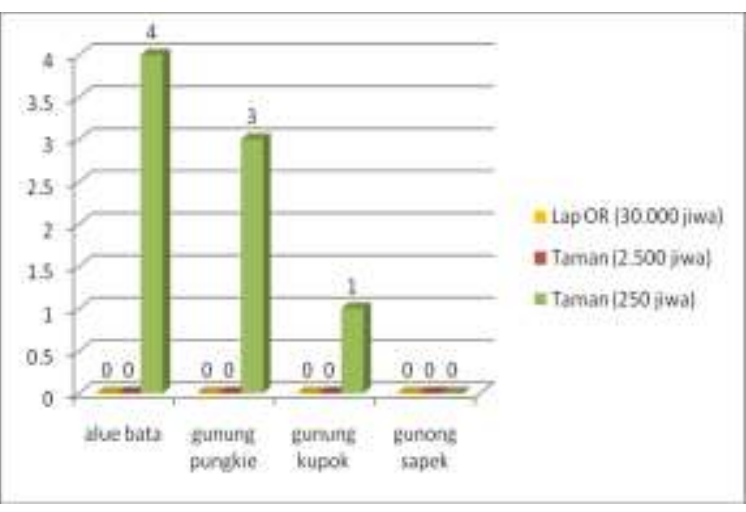

Gambar 11. Rencana Kebutuhan Tambahan Fasilitas Olah Raga dan Rekreasi di Ibukota Kecamatan Tadu Raya Tahun 2031

Berdasarkan SNI 03-1733-2004, kriteria penyediaan makam adalah lahan yang dibutuhkan $2 \mathrm{~m}^{2}$ per penduduk dengan jarak antar makam minimal $0,5 \mathrm{~m}$. Besarnya lahan berkaitan erat dengan besarnya angka kematian di wilayah perencanaan. Pada kondisi eksisting luasan makam di lbukota Kecamatan Tadu Raya adalah $1.120 \mathrm{~m}^{2}$ yang terletak di Desa Alue Bata. Arahan dan pola sebaran RTH di tiap desa di wilayah Ibukota Kecamatan Tadu Raya, dimana daerah sebaran tersebut berdasarkan penggunaan lahan yang telah ada dengan mengutamakan penggunaan lahan dengan nilai landrent yang rendah yaitu diutamakan tanah kosong, semak, dan pepohonan. Arahan persebaran fasilitas olah raga dan rekresi di wilayah penelitian pada tahun 2011-2031 dapat dilihat pada gambar 12 .

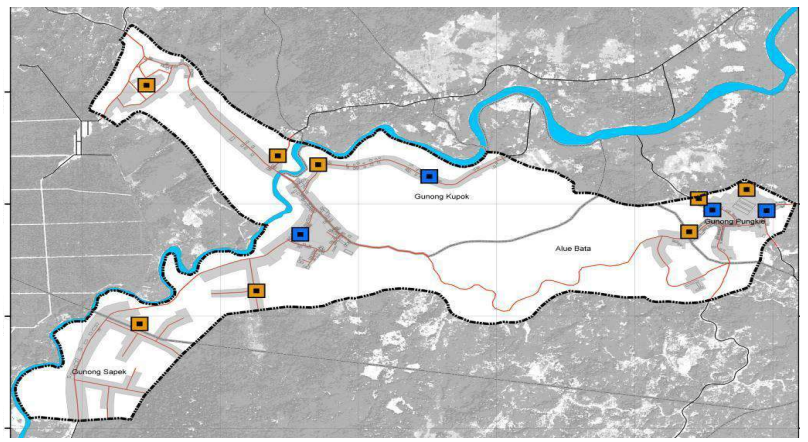

[ RTH Eksisting

$\square$ RTH Rencanc

Gambar 12. Peta Rencana Fasilitas Olah Raga dan Rekreasi di lbukota Kecamatan Tadu Raya

Tahun 2011-2031

\section{KESIMPULAN}

Identifikasi dan distribusi ruang terbuka hijau wilayah penelitian dapat disimpulkan bahwa $79,54 \mathrm{~m}^{2}(0,0012 \%)$ dengan distribusi terbesar di Desa Gunong Pungkie. Jenis ruang terbuka hijau di wilayah penelitian antara lain lapangan sepak bola di Desa Gunong Pungkie, lapangan bola volley di Desa Gunong Pungkie dan Alue Bata, serta pemakaman umum di Desa Alue Bata.

Berdasarkan proyeksi penduduk lbukota Kecamatan Tadu Raya, pada tahun 2031dibutuhkan penambahan ruang terbuka hijau berupa taman bermain skala RT (seluas $250 \mathrm{~m}^{2}$ ) sebanyak 4 unit di Desa Alue Bata, 3 unit di Desa Gunong Pungkie, dan 1 unit di Desa Gunong Kupok. Sedangkan kebutuhan makam hingga tahun 2031 masih dapat terpenuhi oleh makam eksisting yang tersedia di Desa Alue Bata.

Beberapa saran yang dapat diberikan terkait dengan arahan pola penyebaran ruang terbuka hijau di Ibukota Kecamatan Tadu Raya diantaranya adalah (1) dapat dilakukan studi lebih lanjut mengenai arahan pola penyebaran ruang terbuka hijau berdasarkan kemampuan dan kesesuaian lahan dan (20 perlu adanya studi yang dapat melengkapi yaitu mengenai persepsi dan preferensi masyarakat di lbukota Kecamatan Tadu Raya dalam menentukan lokasi taman bermain dan lapangan olah raga. 


\section{DAFTAR PUSTAKA}

Anonim. RTRW Kabupaten Nagan Raya Tahun 2008-2018. Nagan Raya: Bapekab Nagan Raya.

Badan Pusat Statistik. 2007. Kecamatan Tadu Raya Dalam Angka 2006.

Badan Pusat Statistik. 2008. Kecamatan Tadu Raya Dalam Angka 2007.

Badan Pusat Statistik. 2009. Kecamatan Tadu Raya Dalam Angka 2008.

Badan Pusat Statistik. 2010. Kecamatan Tadu Raya Dalam Angka 2009.

Badan Pusat Statistik. 20011. Kecamatan Tadu Raya Dalam Angka 2010.

Departemen Dalam Negeri. 1988. Intruksi Mendagri No. 4 tahun 1988 tentang Ruang Terbuka Hijau. Jakarta.

Departemen Pekerjaan Umum. 2004. SNI 03-1698-2004 Tentang Tata cara Perencanaan Lingkungan Perumahan Sederhana Tidak Bersusun Di Daerah Perkotaan. Jakarta

Departemen Pekerjaan Umum. 2004. SNI 03-1733-2004 Tata Cara Perencanaan Lingkungan Perumahan di Perkotaan. Jakarta

Departemen Pekerjaan Umum. 2007. Peraturan Menteri Pekerjaan Umum No. 06 Tahun 2007 tentang Pedoman Umum Rencana Tata Bangunan dan Lingkungan. Jakarta.

Direktorat Jenderal Penataan Ruang Departemen Pekerjaan Umum. 2006. Ruang Terbuka Hijau, sebagai Unsur Utama Tata Ruang Kota. Jakarta. 